\title{
A Study of Obesity Prevalence in the Rural Population in Turkey: Güzelyurt (Aksaray) Example
}

\section{Türkiye'de Kırsal Nüfusta Obezite Sıklığı Üzerine Bir Araştırma: Güzelyurt (Aksaray) Örneği}

\author{
(D) Derya IŞIKLAR ÖZBERK¹, iD Ömer ÖZBERK²
}

${ }^{1}$ Aksaray Provincial Health Directorate, Family Medicine, Aksaray, Turkey

${ }^{2}$ Aksaray University Training and Research Hospital, Clinic of Radyology, Aksaray, Turkey

\section{ABSTRACT}

Objective: Obesity is a common health problem in almost all societies. The aim of this study was to investigate obesity in rural areas.

Methods: Descriptive, cross-sectional study included patients who applied to Güzelyurt District Hospital in September-November 2018 for any reason over 18 years of age. Body weight, height, body mass index (BMI), waist/hip circumference ratio (WHR), waistto-height ratio (WHtR), and blood pressure measurements were evaluated. In addition, age, gender, marital status, education level, occupation, smoking habits, the disease was diagnosed, whether the drug was recorded.

Results: The mean age of the 191 participants was $46.8 \pm 15.6$ years, $79.1 \%$ were female, $36.6 \%$ were primary school graduates, $72.8 \%$ were housewives, $85.9 \%$ living in town or village. The frequency of obesity $46.6 \%, 51.7 \%$ in females, $27.5 \%$ in males. Abdominal obesity; according to WC, $25.0 \%$ males, $68.2 \%$ females, according to WHR, $70.0 \%$ males, $57.6 \%$ females, and according to WHtR, $77.5 \%$ males and $90.7 \%$ females. There was a moderate positive correlation between the age and BMI. BMI was strong positively significantly correlated with WHtR, WC and $\mathrm{HC}$, a weaker correlation between BMI to NC and WHR.

Conclusion: The prevalence of obesity was $46.6 \%$. It is possible to say that such a high rate in living conditions does not allow

\section{ÖZ}

Amaç: Obezite, hemen hemen tüm toplumlarda yaygın görülen bir sağlık sorunudur. Bu çalışmanın amacı kırsal kesimdeki obeziteyi araştırmaktır.

Yöntemler: Tanımlayıcı, kesitsel tipteki bu araştırmaya Eylül 2018Kasım 2018 tarihleri arasında Güzelyurt İlçe Devlet Hastanesi aile hekimliği polikliniğine 18 yaş ve üzeri herhangi bir nedenle müracaat eden hastalar dahil edildi. Tüm katılımcıların vücut ağırlığı, boy, beden kitle indeksi (BKI), bel/kalça çevresi oranı (BKO), bel-boy oranı, boyun çevresi (ByÇ) ve kan basıncı ölçümleri değerlendirildi. Ayrıca yaş, cinsiyet, medeni durum, eğitim düzeyi, meslek, sigara kullanım alışkanlığı, tanı aldığı hastalık ve kullandığı ilaç olup olmadığı kaydedildi.

Bulgular: Çalışmaya kabul edilen 191 katılımcının yaş ortalaması $46,8 \pm 15,6$ yıl (19-85) \%79,1'i kadın, \%36,6's1 ilkokul mezunu, \%72,8'i ev hanımı, \%85,9'u kasaba veya köyde yaşamakta idi. BKİne göre obezite sıklığı genelde \%46,6, kadınlarda \%51,7, erkeklerde \%27,5 olarak saptandı. Abdominal obezite sıklığı; BÇ’ye göre erkeklerde $\% 25,0$, kadınlarda $\% 68,2$, BKO'ya göre erkeklerde $\% 70,0$, kadınlarda \%57,6 ve bel/boy oranına göre erkeklerde $\% 77,5$, kadınlarda \%90,7 olarak bulundu. Katılımcıların yaşı ile BKİ arasındaki korelasyon incelendiğinde pozitif yönde orta derecede bir korelasyon saptandı BKİ ile bel-boy oranı, BÇ ve $\mathrm{KÇ}$ arasında pozitif yönde çok kuvvetli derecede bir korelasyon saptanmasına rağmen, BKİ ile BynÇ ve BKO arasında pozitif yönde daha zayıf bir korelasyon mevcuttu.

Address for Correspondence: Derya IŞIKLAR ÖZBERK, Aksaray Provincial Health Directorate, Family Medicine, Aksaray, Turkey

E-mail: derya_isiklar@hotmail.com ORCID ID: orcid.org/0000-0003-0984-8860 
sedentary life and families with low socioeconomic status have such a high rate. Obesity is health problem of our age in rural areas.

Keywords: Obesity prevalence, rural, body mass index, waist-toheight ratio, waist/hip circumference ratio, neck circumference
Sonuç: Bu çalışmada obezite prevalansı \%46.6 olarak tespit edildi. Yaşam koşulları sedanter yaşama elvermeyen, sosyoekonomik düzeyi düşük ailelerin çoğunlukta olduğu bir ilçede bu kadar yüksek bir oran saptamamız obezitenin kırsalda da çağımızın en önemli sağlık sorunu olduğunu söylemek mümkündür.

Anahtar Sözcükler: Obezite prevalansı, kırsal, beden kitle indeksi, bel-boy oranı, bel/kalça çevresi oranı, boyun çevresi

\section{Introduction}

Obesity is defined by the World Health Organization (WHO) as the accumulation of excess fat in the body to the extent that it disrupts human health. It is a common public health problem all over the world. The WHO reported in 2016 that the the country with the highest prevalence of obesity in Europe was Turkey with the rate of $29.5 \%$ (1). According to the studies of TURDEP-I (1998) and TURDEP-II (2010) conducted with an interval of twelve years in the adult population in our country and in the same centers, the prevalence of obesity increased from $22.3 \%$ $(32.9 \%$ in women, $13.2 \%$ in men) to $31.2 \%$ (44.2\% in women, $27.3 \%$ in men) (2).

Although obesity is mostly a problem of developed countries, it is estimated that the prevalence of obesity is increasing rapidly in developing countries. Knowing the body fat distribution is important in predicting the health problems that may be related and determining the risk factors. Performing some anthropometric measurements contributes to the determination of these risk factors (3). Increased waist circumference (WC) or waist/hip ratio (WHR) is defined as abdominal (central or visceral) obesity. Abdominal obesity is an important risk factor for cardiovascular problems. It has been reported that waist circumference in particular reflects the current risk better as an indicator of abdominal obesity (4).

Overweight is defined as body mass index (BMI) of $25 \mathrm{~kg} / \mathrm{m}^{2}$ or above, and obesity as $30 \mathrm{~kg} / \mathrm{m}^{2}$ or above. Abdominal obesity is a waist circumference of $88 \mathrm{~cm}$ or above for women and 102 $\mathrm{cm}$ or above for men (5). The frequency of abdominal obesity was found to be $64.3 \%$ in women and $34.6 \%$ in men in the TURDEP-II study (6).

The aim of this study was to determine the prevalence of obesity with anthropometric measurements in adults whose living conditions did not allow for sedentary life, in a rural district where families with low socioeconomic levels were in the majority and to determine the sociodemographic status of obese people. In the literature review, no clear data showing the prevalence of obesity in Aksaray province and its districts was found, and our study was intended to be a guide on this issue.

\section{Method}

In this descriptive, cross-sectional study, patients aged 18 or over who were admitted to the District State Hospital General Outpatient Clinic between September 2018 and November
2018 for any reason were included. Before starting the study, the study was approved by The Aksaray University Ethics Committee with the number 152 on 10.07.2018. Afterwards, administrative permission was obtained from the Provincial Health Directorate.

\section{Data Collection}

Sociodemographic characteristics, smoking and chronic illnesses status, drug use, height, weight, WC, hip circumference (HC), neck circumference (NC), and blood pressure (BP) values were recorded in the questionnaire form previously prepared by the researcher. Before starting the study, the participants were informed about the study and their verbal consent was obtained. Individuals whose standing height and weight could not be measured, those under the age of 18 and those who did not want to participate in the study voluntarily were excluded from the study.

The prevalence of obesity in our country has been found to be $35 \%$ in studies based on the general population (1).

\section{Anthropometric Measurements}

By the same researcher, the heights of the patients were measured after removing the shoes, and the weights of the patients were measured after removing the jacket and excess clothes with an adult digital scales with height measurement (weight sensitivity range $100 \mathrm{~g}$ ). While the patients were standing, WC was measured from the midpoint between the lowest rib and lateral iliac spurs, and $\mathrm{HC}$ was measured at the level of the greater trochanters. The NC was measured at the superior edge of the cricothyroid membrane while the patients were awake and standing. All measurements were made by the same person and the results were rounded to the nearest $0.5 \mathrm{~cm}$ value to reduce the person's margin of error.

BMI was determined with the formula of weight $(\mathrm{kg}) /$ height $(\mathrm{m})^{2}$.

- $\mathrm{BMI} \leq 18.5 \mathrm{~kg} / \mathrm{m}^{2}$ underweight

- BMI between 18.5-24.99 kg/m² normal weight

- BMI between 25.00-29.99 kg/m² overweight

- $\mathrm{BMI} \geq 30 \mathrm{~kg} / \mathrm{m}^{2}$ obese

-BMI between 30.00-34.99 kg/m² mild obese

- BMI between $35.00-39.99 \mathrm{~kg} / \mathrm{m}^{2}$ moderate obese 
-BMI between 40.00-49.99 kg/m² morbid obese

-BMI $\geq 50 \mathrm{~kg} / \mathrm{m}^{2}$ super obese

Abdominal obesity criteria; waist circumference $\geq 100 \mathrm{~cm}$ for men, $\geq 90 \mathrm{~cm}$ for women, waist circumference to hip circumference ratio $>0.85$ and waist-height ratio $\geq 0.5$ (1).

\section{Statistical Analysis}

Statistical analyzes were performed using SPSS version 20 software. The normal distribution of the variables was examined by visual (histogram and probability graphics) and analytical methods (Kolmogorov-Smirnov/Shapiro-Wilk tests). Descriptive analyzes were given for variables without normal distribution, using median and minimum-maximum values (and frequency tables for ordinal variables). Since it was determined that WC, $\mathrm{HC}, \mathrm{NC}$, systolic and diastolic blood pressure variables did not show normal distribution, these and the ordinal BMI variable were compared using the Kruskal-Wallis test. Chi-Square test was used to compare categorical data. Pearson's correlation analysis was used to determine the relationship between numerical variables. The significance was evaluated at the $\mathrm{p}<0.05$ level and the results were evaluated within the $95 \%$ confidence interval. Correlation coefficient (r); between 0.00-0.24 was determined as weak, between $0.25-0.49$ as medium, between $0.50-0.74$ as strong, and between $0.75-1.00$ as very strong.

\section{Results}

The mean age of the 191 patients included in our study was $46.8 \pm 15.6$ years (min: 19, $\max : 85$ ). Of the participants, $79.1 \%(n=151)$ were female, $20.9 \%(n=40)$ were male, $36.6 \%$ $(\mathrm{n}=70)$ were primary school graduates, $72.8 \%(\mathrm{n}=139)$ were housewives, \% $85.9(\mathrm{n}=164)$ were living in a town or village. Of the participants, $11.5 \%(n=22)$ were current smokers (Table 1 ). The mean systolic BP was $123.69 \pm 14.33 \mathrm{mmHg}$ and the mean diastolic BP was $75.35 \pm 8.57 \mathrm{mmHg}$. In anthropometric measurements; average height was $1.58 \pm 0.08 \mathrm{~m}$ (1.40-1.94), average weight was $73.80 \pm 13.39 \mathrm{~kg}(45-110)$, mean WC was $94.65 \pm 12.92 \mathrm{~cm}(60-124)$, mean $\mathrm{HC}$ was $108.56 \pm 12.76$ $\mathrm{cm}$ (72-145), and mean NC was $37.17 \pm 3.91 \mathrm{~cm}(29-46)$. According to $\mathrm{BMI}, 1.0 \%$ of the participants were underweight $(n=2), 22.0 \%(n=42)$ were normal weight, 30.4\% ( $n=58)$ were overweight, $46.6 \%(n=89)$ were found to be obese (Figure 1). According to BMI, the frequency of obesity was $51.7 \%$ in women and $27.5 \%$ in men. The frequency of abdominal obesity was $25.0 \%(n=10 / 40)$ in men, $68.2 \%$ in women $(n=103 / 151)$ according to WC, $70.0 \%$ in men $(n=28 / 40)$ and $57.6 \%$ in women $(n=87 / 151)$ according to WHR, and $77.5 \%(n=31 / 40)$ in men and $90.7 \%(n=137 / 151)$ in women according to the waist/height ratio.

In our research, some variables were compared in the 3 groups we classified according to BMI (Table 2). Median values of WC, $\mathrm{HC}, \mathrm{BMI}$, systolic BP were significantly higher in the normal weight group than the normal-underweight group $(\mathrm{p}<0.001$, $\mathrm{p}<0.001, \mathrm{p}=0.007$, and $\mathrm{p}=0.001$, respectively). Median systolic and diastolic BP values were significantly higher in the obese group compared to the normal-underweight group $(\mathrm{p}<0.001$ and $\mathrm{p}=0.001$, respectively). In addition, systolic BP value was significantly higher in the obese group compared to the overweight group ( $\mathrm{p}=0.002)$ (Figure 2).

The comparison of various sociodemographic characteristics of obese and non-obese participants is given in Table 3. According

Table 1. Sociodemographic characteristics of the participants

\begin{tabular}{|c|c|c|}
\hline \multicolumn{3}{|c|}{ participarics } \\
\hline & $\mathrm{n}$ & $\%$ \\
\hline \multicolumn{3}{|l|}{ Gender } \\
\hline Female & 151 & 79.1 \\
\hline Male & \multirow[t]{2}{*}{40} & \multirow[t]{2}{*}{20.9} \\
\hline $\begin{array}{l}\text { Age (median: } 45, \text { min: } 19, \text { max: } 85 \\
\text { years) }\end{array}$ & & \\
\hline $18-35$ years & 52 & 27.2 \\
\hline $36-55$ years & 83 & 43.5 \\
\hline$>55$ years & 56 & 29.3 \\
\hline \multicolumn{3}{|l|}{ Education status } \\
\hline Illiterate & 28 & 14.7 \\
\hline Literate & 30 & 15.7 \\
\hline Primary school & 70 & 36.6 \\
\hline Middle school & 21 & 11.0 \\
\hline High school & 24 & 12.6 \\
\hline College-university & 18 & 9.4 \\
\hline \multicolumn{3}{|l|}{ Occupation } \\
\hline Housewife & 139 & 72.8 \\
\hline Officer & 15 & 7.9 \\
\hline Retired & 23 & 12.0 \\
\hline Worker & 8 & 4.2 \\
\hline Student & 6 & 3.1 \\
\hline \multicolumn{3}{|l|}{ Marital status } \\
\hline Married & 152 & 79.6 \\
\hline Single & 24 & 12.6 \\
\hline Widow & 15 & 7.8 \\
\hline \multicolumn{3}{|l|}{ Income level of family } \\
\hline$<500 \mathrm{TL} /$ month & 24 & 12.6 \\
\hline 500-1000 TL/month & 46 & 24.1 \\
\hline $1001-2000 \mathrm{TL} / \mathrm{month}$ & 81 & 42.4 \\
\hline$>2000$ TL/month & 40 & 20.9 \\
\hline \multicolumn{3}{|l|}{ Living place } \\
\hline District center & 27 & 14.1 \\
\hline Town & 152 & 79.6 \\
\hline Village & 12 & 6.3 \\
\hline \multicolumn{3}{|l|}{ Smoking status } \\
\hline Yes & 22 & 11.5 \\
\hline Never smoked & 152 & 79.6 \\
\hline Left & 17 & 8.9 \\
\hline Total & 191 & 100.0 \\
\hline
\end{tabular}


to this; the frequency of obesity was significantly higher in the group aged 45 or over than in the group under 45 years of age $(\mathrm{p}<0.001)$. The BMI in the group aged 45 or over was 3.669 times higher than in those under 45 years of age $[\mathrm{OR}=$ 3.669, 95\% CI; (2.012-6.693)]. The incidence of obesity was statistically significantly higher in the non-working group than in the working group, and in those with education level of primary school or below, compared to the group with high school or above $(p<0.001)$. Obesity was found to be significantly higher in patients with a diagnosed disease than in patients without a diagnosed disease $(\mathrm{p}=0.006)$.

When the correlation between participants' age and BMI was examined, a moderate positive correlation was found $(r=0.407$, $\mathrm{p}=0.000$ ) (Table 4). When linear regression analysis was

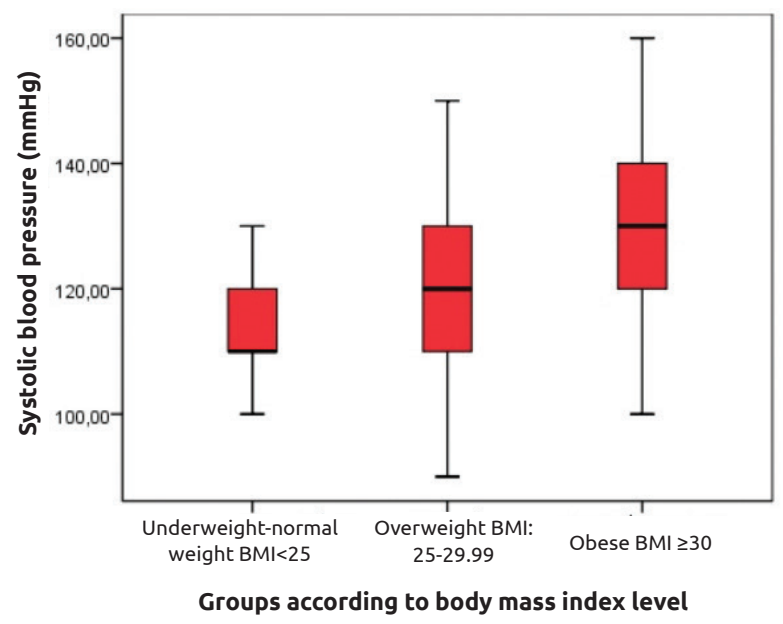

Figure 1. Relationship between body mass index (BMI) and systolic blood pressure values performed, $16.5 \%$ of the increase in BMI was attributed to the increase in age $\left(\mathrm{R}^{2}=0.165\right)$ (Figure 3$)$. When the correlation between WC and NC was examined, a moderate positive correlation was found $(r=0.455, p=0.000)$. When the correlation between $\mathrm{HC}$ and $\mathrm{NC}$ was examined, a moderately significant positive correlation was found $(\mathrm{r}=0.429, \mathrm{p}=0.000)$ (Table 4). The variables showing the best correlation coefficient value with systolic BP in all participants were BMI $(r=0.504, p<0.001)$ and waist/height ratio $(\mathrm{p}<0.001 ; \mathrm{r}=0.454)$, respectively. The variables showing the best correlation coefficient value with diastolic BP were determined as age $(\mathrm{r}=0.391, \mathrm{p}<0.001)$ and waist/height

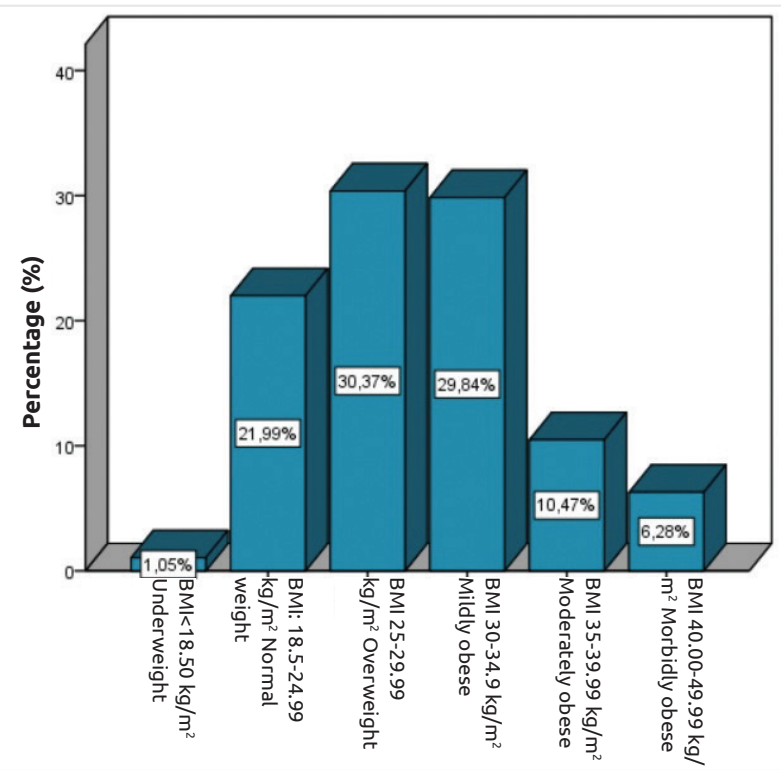

Figure 2. Classification of patients according to their body mass index (BMI)

\begin{tabular}{|c|c|c|c|c|c|}
\hline \multirow{2}{*}{ Variables } & $\begin{array}{l}\mathrm{BMI}<25 \mathrm{~kg} / \mathrm{m}^{2}(\mathrm{a}) \\
(\mathrm{n}=44)\end{array}$ & $\begin{array}{l}\text { BMI } 25-29.99 \mathrm{~kg} / \mathrm{m}^{2}(\mathrm{~b}) \\
(\mathrm{n}=58)\end{array}$ & $\begin{array}{l}\mathrm{BMI} \geq 30 \mathrm{~kg} / \mathrm{m}^{2}(\mathrm{c}) \\
(\mathrm{n}=89)\end{array}$ & \multirow[b]{2}{*}{$x^{2}$} & \multirow[b]{2}{*}{$\mathrm{p}$} \\
\hline & $\begin{array}{l}\text { Median } \\
\text { (min-max) }\end{array}$ & $\begin{array}{l}\text { Median } \\
\text { (min-max) }\end{array}$ & $\begin{array}{l}\text { Median } \\
\text { (min-max) }\end{array}$ & & \\
\hline Waist circumference $(\mathrm{cm})$ & $81.0(60.0-102.0)$ & $91.5(68.0-110.0)$ & $103.0(82.0-124.0)$ & 90.127 & $\begin{array}{l}<0.001 a b * \\
<0.001 a c^{*} \\
<0.001 b^{*}\end{array}$ \\
\hline Hip circumference (cm) & $95.0(78.0-122.0)$ & $108.0(72.00-121.00)$ & $117.0(101.0-145.0)$ & 91.435 & $\begin{array}{l}<0.001 \mathrm{ab}^{*} \\
<0.001 \mathrm{ac} * \\
<0.001 \mathrm{bc}^{*}\end{array}$ \\
\hline Neck circumference (cm) & $35.0(29.0-41.0)$ & $37.0(30.0-45.0)$ & $39.0(29.0-46.0)$ & 25.356 & $\begin{array}{l}0.007 a b * \\
<0.001 a c^{*} \\
0.004 b c^{*}\end{array}$ \\
\hline $\begin{array}{l}\text { Systolic blood pressure } \\
(\mathrm{mmHg})\end{array}$ & $110.0(90.0-160.0)$ & $120.0(90.0-150.0)$ & $130.0(100.0-160.0)$ & 36.868 & $\begin{array}{l}0.001 a b^{*} \\
<0.001 a c^{*} \\
0.002 b c^{*}\end{array}$ \\
\hline $\begin{array}{l}\text { Diastolic blood pressure } \\
\text { (mmHg) }\end{array}$ & $70.0(60.0-90.0)$ & $75.0(60.0-90.0)$ & $76.0(60.0-100.0)$ & 10.457 & $0.001 \mathrm{ac} *$ \\
\hline
\end{tabular}




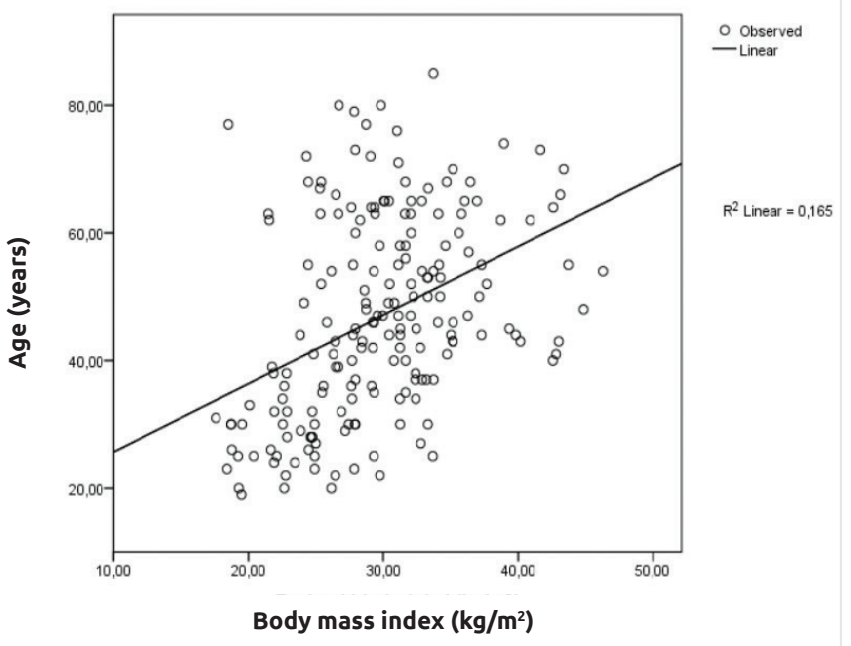

Figure 3. Linear regression analysis between age and body mass index

$\mathrm{R} 2$ =Coefficient of determination $(R 2=0.165, p=0.000)$ ratio $(\mathrm{r}=0.309, \mathrm{p}<0.001)$, respectively. When the correlation between anthropometric measurement variables was examined, there was a very strong positive correlation between BMI and waist/height ratio, WC and $\mathrm{HC}(\mathrm{r}=0.826, \mathrm{p}<0.001, \mathrm{r}=0.769$, $\mathrm{p}<0.001 ; \mathrm{r}=0.751, \mathrm{p}<0.001)$, a very strong positive correlation BMI and waist/height ratio $(r=0.826, p<0.001)$ between BMI and WC $(\mathrm{r}=0.769, \mathrm{p}<0.001)$ and a very strong positive correlation between BMI and HS $(r=0.769, \mathrm{p}<0.001)=0.751, \mathrm{p}<0.001)$. In addition, a strong positive correlation between BMI and $\mathrm{NC}$ $(\mathrm{r}=0.504, \mathrm{p}<0.001)$ and a weak positive correlation between BMI and WHR ( $\mathrm{r}=0.196, \mathrm{p}<0.001)$ were found (Table 4).

\section{Discussion}

While smoking is the first cause of preventable deaths in our era, the second important reason is obesity. The prevalence of obesity is above the critically high value of $30 \%$ in the adult population in our country. In our study, it was determined that $30.4 \%$ of the participants were overweight and $46.6 \%$ were obese according to BMI. The frequency of obesity according to BMI was $51.7 \%$ in

Table 3. Relationship between some demographic features and body mass indexes

\begin{tabular}{|c|c|c|c|c|c|c|c|c|c|}
\hline \multirow{2}{*}{$\begin{array}{l}\text { Variables } \\
\text { n }\end{array}$} & & \multicolumn{2}{|c|}{$\begin{array}{l}\mathrm{BMI}<30 \mathrm{~kg} / \mathrm{m}^{2} \\
(\mathrm{n}=102)\end{array}$} & \multicolumn{2}{|c|}{$\begin{array}{l}\mathrm{BMI} \geq 30 \mathrm{~kg} / \mathrm{m}^{2} \\
(\mathrm{n}=89)\end{array}$} & \multicolumn{2}{|c|}{$\begin{array}{l}\text { Total } \\
(n=191)\end{array}$} & \multirow{2}{*}{$x^{2}$} & \multirow{2}{*}{$P$} \\
\hline & & $\%$ & $\mathrm{n}$ & $\%$ & $\mathrm{n}$ & $\%$ & & & \\
\hline Age & $\begin{array}{l}<45 \text { years } \\
\geq 45 \text { years }\end{array}$ & $\begin{array}{l}64 \\
38\end{array}$ & $\begin{array}{l}69.6 \\
38.4\end{array}$ & $\begin{array}{l}28 \\
61\end{array}$ & $\begin{array}{l}30.4 \\
61.6\end{array}$ & $\begin{array}{l}92 \\
99\end{array}$ & $\begin{array}{l}100.0 \\
100.0\end{array}$ & 18.632 & $<0.001$ \\
\hline Gender & $\begin{array}{l}\text { Female } \\
\text { Male }\end{array}$ & $\begin{array}{l}73 \\
29\end{array}$ & $\begin{array}{l}48.3 \\
72.5\end{array}$ & $\begin{array}{l}78 \\
11\end{array}$ & $\begin{array}{l}51.7 \\
27.5\end{array}$ & $\begin{array}{l}151 \\
40\end{array}$ & $\begin{array}{l}100.0 \\
100.0\end{array}$ & 7.415 & 0.006 \\
\hline Education status & $\begin{array}{l}\text { Primary school or below } \\
\text { High school or above }\end{array}$ & $\begin{array}{l}69 \\
33\end{array}$ & $\begin{array}{l}46.3 \\
78.6\end{array}$ & $\begin{array}{l}80 \\
9\end{array}$ & $\begin{array}{l}53.7 \\
21.4\end{array}$ & $\begin{array}{l}149 \\
42\end{array}$ & $\begin{array}{l}100.0 \\
100.0\end{array}$ & 13.705 & $<0.001$ \\
\hline Marital status & $\begin{array}{l}\text { Married } \\
\text { Single }\end{array}$ & $\begin{array}{l}78 \\
24\end{array}$ & $\begin{array}{l}51.3 \\
61.5\end{array}$ & $\begin{array}{l}74 \\
15\end{array}$ & $\begin{array}{l}48.7 \\
38.5\end{array}$ & $\begin{array}{l}152 \\
39\end{array}$ & $\begin{array}{l}100.0 \\
100.0\end{array}$ & 1.303 & 0.254 \\
\hline Living place & $\begin{array}{l}\text { District center } \\
\text { Village-town }\end{array}$ & $\begin{array}{l}14 \\
88\end{array}$ & $\begin{array}{l}51.9 \\
53.7\end{array}$ & $\begin{array}{l}13 \\
76\end{array}$ & $\begin{array}{l}48.1 \\
46.3\end{array}$ & $\begin{array}{l}27 \\
164\end{array}$ & $\begin{array}{l}100.0 \\
100.0\end{array}$ & 0.030 & 0.862 \\
\hline Occupation & $\begin{array}{l}\text { Working } \\
\text { Not working }\end{array}$ & $\begin{array}{l}41 \\
61\end{array}$ & $\begin{array}{l}78.8 \\
43.9\end{array}$ & $\begin{array}{l}11 \\
78\end{array}$ & $\begin{array}{l}21.2 \\
56.1\end{array}$ & $\begin{array}{l}52 \\
139\end{array}$ & $\begin{array}{l}100.0 \\
100.0\end{array}$ & 18.588 & $<0.001$ \\
\hline Income level & $\begin{array}{l}<1,000 \mathrm{TL} \\
\geq 1,000 \mathrm{TL}\end{array}$ & $\begin{array}{l}27 \\
75\end{array}$ & $\begin{array}{l}38.6 \\
62.0\end{array}$ & $\begin{array}{l}43 \\
46\end{array}$ & $\begin{array}{l}61.4 \\
38.0\end{array}$ & $\begin{array}{l}70 \\
121\end{array}$ & $\begin{array}{l}100.0 \\
100.0\end{array}$ & 9.768 & 0.002 \\
\hline Type of family & $\begin{array}{l}\text { Nuclear family } \\
\text { Extended family }\end{array}$ & $\begin{array}{l}90 \\
12\end{array}$ & $\begin{array}{l}55.2 \\
42.9\end{array}$ & $\begin{array}{l}73 \\
16\end{array}$ & $\begin{array}{l}44.8 \\
25.1\end{array}$ & $\begin{array}{l}163 \\
28\end{array}$ & $\begin{array}{l}100.0 \\
100.0\end{array}$ & 1.466 & 0.226 \\
\hline Smoking & $\begin{array}{l}\text { Current smoker } \\
\text { Not smoking }\end{array}$ & $\begin{array}{l}18 \\
84\end{array}$ & $\begin{array}{l}81.8 \\
49.7\end{array}$ & 4 & $\begin{array}{l}18.2 \\
50.3\end{array}$ & 22 & $\begin{array}{l}100.0 \\
100.0\end{array}$ & 8.068 & 0.005 \\
\hline Diagnosis of a disease & $\begin{array}{l}\text { Yes } \\
\text { No }\end{array}$ & $\begin{array}{l}35 \\
67\end{array}$ & $\begin{array}{l}42.2 \\
62.0\end{array}$ & $\begin{array}{l}41 \\
41\end{array}$ & $\begin{array}{l}57.8 \\
38.0\end{array}$ & $\begin{array}{l}83 \\
108\end{array}$ & $\begin{array}{l}100.0 \\
100.0\end{array}$ & 7.445 & 0.006 \\
\hline Drug use & $\begin{array}{l}\text { Yes } \\
\text { No }\end{array}$ & $\begin{array}{l}33 \\
69\end{array}$ & $\begin{array}{l}41.8 \\
61.6\end{array}$ & 43 & $\begin{array}{l}58.2 \\
38.4\end{array}$ & $\begin{array}{l}79 \\
112\end{array}$ & $\begin{array}{l}100.0 \\
100.0\end{array}$ & 7.324 & 0.007 \\
\hline
\end{tabular}


Table 4. Correlation status between some variables

\begin{tabular}{|c|c|c|c|c|c|c|c|c|c|c|c|}
\hline Değişkenler & Age & Height & Weight & WC & $\mathrm{HC}$ & NC & SBP & DBP & WHR & BMI & WHeR \\
\hline \multicolumn{12}{|l|}{ Age } \\
\hline \multicolumn{12}{|l|}{$r$} \\
\hline$p$ & 1 & & & & & & & & & & \\
\hline n & 191 & & & & & & & & & & \\
\hline \multicolumn{12}{|l|}{ Height } \\
\hline r & $-0.334 * *$ & & & & & & & & & & \\
\hline$p$ & 0.000 & 1 & & & & & & & & & \\
\hline$n$ & 191 & 191 & & & & & & & & & \\
\hline \multicolumn{12}{|l|}{ Weight } \\
\hline r & $0.264^{* *}$ & 0.099 & & & & & & & & & \\
\hline $\mathrm{p}$ & 0.000 & 0.175 & 1 & & & & & & & & \\
\hline n & 191 & 191 & 191 & & & & & & & & \\
\hline \multicolumn{12}{|l|}{ WC } \\
\hline$r$ & $0.472 * *$ & $-0.163^{*}$ & $0.759 * *$ & & & & & & & & \\
\hline $\mathrm{P}$ & 0.000 & 0.024 & 0.000 & 1 & & & & & & & \\
\hline n & 191 & 191 & 191 & q191 & & & & & & & \\
\hline \multicolumn{12}{|l|}{ HC } \\
\hline г & $0.397 * *$ & $-0.258 * *$ & $0.682 * *$ & $0.798 * *$ & & & & & & & \\
\hline $\mathrm{P}$ & 0.000 & 0.000 & 0.000 & 0.000 & 1 & & & & & & \\
\hline n & 191 & 191 & 191 & 191 & q191 & & & & & & \\
\hline \multicolumn{12}{|l|}{ NC } \\
\hline r & $0.258^{* *}$ & -0.129 & $0.467^{* *}$ & $0.455^{* *}$ & $0.429 * *$ & & & & & & \\
\hline $\mathrm{P}$ & 0.000 & 0.075 & 0.000 & 0.000 & 0.000 & 1 & & & & & \\
\hline n & 191 & 191 & 191 & 191 & 191 & q191 & & & & & \\
\hline \multicolumn{12}{|l|}{ SBP } \\
\hline r & $0.423 * *$ & $-0.285^{* *}$ & $0.392 * *$ & $0.418 * *$ & $0.393 * *$ & $0.232 * *$ & & & & & \\
\hline$p$ & 0.000 & 0.000 & 0.000 & 0.000 & 0.000 & 0.001 & 1 & & & & \\
\hline n & 191 & 191 & 191 & 191 & 191 & 191 & q191 & & & & \\
\hline \multicolumn{12}{|l|}{ DBP } \\
\hline r & 0.391 ** & $-0.154^{*}$ & 0.214 ** & 0.281 ** & $0.211^{* *}$ & $0.260 * *$ & $0.682 * *$ & & & & \\
\hline $\mathrm{P}$ & 0.000 & 0.034 & 0.003 & 0.000 & 0.003 & 0.000 & 0.000 & 1 & & & \\
\hline$n$ & 191 & 191 & 191 & 191 & 191 & 191 & 191 & 191 & & & \\
\hline \multicolumn{12}{|l|}{ WHR } \\
\hline$r$ & $0.218^{* *}$ & 0.104 & $0.281^{* *}$ & $0.505^{* *}$ & -0.111 & 0.137 & 0.120 & $0.153^{*}$ & & & \\
\hline$p$ & 0.000 & 0.152 & 0.000 & 0.000 & 0.127 & 0.060 & 0.098 & 0.035 & 1 & & \\
\hline$n$ & 191 & 191 & 191 & 191 & 191 & 191 & 191 & 191 & 191 & & \\
\hline \multicolumn{12}{|l|}{ BMI } \\
\hline r & $0.407 * *$ & $-0.419 * *$ & $0.857^{* *}$ & $0.769 * *$ & $0.751 * *$ & $0.504 * *$ & $0.508 * *$ & $0.280 * *$ & $0.196 * *$ & & \\
\hline$p$ & 0.000 & 0.000 & 0.000 & 0.000 & 0.000 & 0.000 & 0.000 & 0.000 & 0.007 & 1 & \\
\hline n & 191 & 191 & 191 & 191 & 191 & 191 & 191 & 191 & 191 & 191 & \\
\hline \multicolumn{12}{|l|}{ WHeR } \\
\hline$r$ & $0.533 * *$ & $-0.470 * *$ & $0.645^{* *}$ & $0.946 * *$ & $0.796^{* *}$ & $0.454 * *$ & $0.473 * *$ & $0.309 * *$ & $0.418 * *$ & $0.826 * *$ & \\
\hline $\mathrm{p}$ & 0.000 & 0.000 & 0.000 & 0.000 & 0.000 & 0.000 & 0.000 & 0.000 & 0.000 & 0.000 & 1 \\
\hline n & 191 & 191 & 191 & 191 & 191 & 191 & 191 & 191 & 191 & 191 & 191 \\
\hline
\end{tabular}

* Correlation is significant at 0.05 level, ** Correlation is significant at 0.01 level, WC: Waist circumference, HC: Hip circumference, NC: Neck circumference, SBP: Systolic blood pressure, DBP: Diastolic blood pressure, WHR: Waist/hip ratio, BMI: Body mass index, WHeR: Waist/height ratio, BMI: Body mass index 
women and $27.5 \%$ in men. Similar to our study, the prevalence of obesity was found $51.0 \%$ in women and $15.1 \%$ in men in a study conducted with a total of 1672 adults aged between 25-64 and residing in the working community in Ankara (7). Similarly, in a study conducted in Kocaeli University, the rate of obese women was higher than men among 207 patients who were admitted to the family medicine outpatient clinic (8). In the study conducted by Akman et al., the frequency of obesity was found to be $31.6 \%$ and overweight $33.3 \%$ according to BMI. It was found that obesity gradually increased in the patients starting from the $40 \mathrm{~s}$ and decreased relatively by the age of 60s (9). Similarly, in our study, the frequency of obesity was significantly higher in the 45 years or older group than the group below 45 years. In another study, obesity status was evaluated in housewives and working women and it was reported that weight, WC, BMI, and WHR values among body composition variables were significantly different between groups in favor of working women (10). The reason we found high frequency of obesity in our study might be that women and housewives were in the majority. Similar to our study, the incidence of obesity was statistically significantly higher in the group that did not work compared to the group working, and also in those with education level of primary school or below compared to the group with education level of high school or above. As a matter of fact, in the study of Erkol et al., it was found that there was a relationship between the obesity and occupation, and that housewives were more obese (11). In the study conducted by Baugman et al. (12) in 665 overweight or obese people, it was found that higher BMI was associated with low education level.

In the "National Health and Nutrition Examination Survey" (NHANES) study, it was reported that 5-9.9 kg of excess weight in women with overweight (BMI $25 \mathrm{~kg} / \mathrm{m}^{2}$ or above) increased the risk of developing hypertension 1.7 times, and an excess of $25 \mathrm{~kg}$ or above increased 5.2 times (13). Similarly, in our study, the median systolic and diastolic BP values were found to be significantly higher in the obese group compared to the normalunderweight group, and the systolic BP value was significantly higher in the obese group compared to the overweight group. In addition, the correlation coefficient value of both systolic and diastolic blood pressure and waist/height ratio was found to be higher than WC and WHR measurement.

Measurement of BMI and WC is usually sufficient in the diagnosis of obesity. The most important deficiency of BMI measurement is that it cannot give an idea about the body fat distribution that predicts complications caused by obesity (14). Waist/height ratio is a valid measurement in determining abdominal obesity (15). In a systematic review and metaanalysis study by Ashwell et al. (16), it was shown that waist/ height ratio is a better screening tool for cardiometabolic risk factors for adults than WC. In this study, we hypothesized that waist/height ratio and NC measurements could show body fat distribution together with WC and WHR. Although there was a very strong positive correlation between BMI and waist/height ratio, WC and $\mathrm{HC}$; the correlation coefficient value between BMI and NC and WHR was found to be lower. There was no clear data in the literature about waist/height ratio, NC, and the prevalence of abdominal obesity in rural areas. The frequency of abdominal obesity in our study was $25.0 \%$ in men, $68.2 \%$ in women according to WC, $60.2 \%$ according to WHR and $88 \%$ according to waist/height ratio.

\section{Study Limitations}

First, this study was performed only in the adult population, and obesity is increasing rapidly in childhood and adolescence. Second, this study had a relatively small number of participants. In addition, the ratio of women to men was not equal in the participants, and the higher number of women was the weakness of our study.

\section{Conclusion}

In this study, the prevalence of obesity was determined as $46.6 \%$. We detected obesity at a high rate in a rural district with living conditions that were not suitable for sedentary life, where families with low socioeconomic level were in the majority. People who did not have eating habits of simple and refined sugars called as fast-food, did not reach food easily, and were not lack of physical activity due to spending time with technological devices such as computers at home, lived in this rural district. It is possible to say that obesity is also the most important health problem of our era in the countryside.

\section{Ethics}

Ethics Committee Approval: The Aksaray University Ethics Committee with the number 152 on 10.07.2018. Afterwards, administrative permission was obtained from the Provincial Health Directorate.

Informed Consent: Obtained.

Peer-review: Externally peer reviewed.

\section{Authorship Contributions}

Concept: D.İ.Ö., Design: D.İ.Ö., Ö.Ö., Data Collection or Processing: D.İ.Ö., Analysis or Interpretation: D.İ.Ö., Ö.Ö. Literature Search: D.İ.Ö., Writing: D.İ.Ö., Ö.Ö.

Conflict of Interest: No conflict of interest was declared by theauthors.

Financial Disclosure: The authors declared that this studyreceived no financial support.

\section{References}

1. Türkiye Endokrinoloji ve Metabolizma Derneği. Obezite Tanı Ve Tedavi Kılavuzu 2018. Available from: URL: http://temd.org.tr/ admin/uploads/tbl_kilavuz/20180516162841-2018-05-16tbl_ kilavuz162840.pdf (Erişim tarihi:15 Şubat 2018)

2. Satman İ. Türkiye'de obezite sorunu. Turkiye Klinikleri J Gastroenterohepatol-Special Topics 2016;9:1-11. 
3. Sözmen K, Ünal B, Sakarya S, Dinç G, Yardım N, Keskinkılıç B, et al. Türkiye'de Antropometrik Ölçüm Yöntemlerinin Kardiyovasküler Hastalık Riski İle İlişkisi. Dicle Med J 2016;43:99-106.

4. Schneider HJ, Glaesmer H, Klotsche J, Böhler S, Lehnert H, Zeiher AM, et al. Accuracy of anthropometric indicators of obesity to predict cardiovascular risk. J Clin Endocrinol Metab 2007;92:589-94.

5. World Health Organization. Report of a WHO consultation on obesity. Geneva: WHO Press; 1997. Available from: URL: https:// apps.who.int/iris/handle/10665/63854

6. Satman İ, İmamoğlu Ş, Yılmaz C, Ayvaz G, Çömlekçi A. Türkiye'de ve Dünyada diyabet. Turk J Endocrinol Metab 2012;16:1-56.

7. Tezcan S, Altintaş H, Sönmez R, Akinci A, Doğan B, Cakir B, et al. Cardiovascular risk factor levels in a lower middle-class community in Ankara, Turkey. Trop Med Int Health 2003;8:660-7.

8. Aladağ N, Ciğerli Ö, Topsever P, Topallı R, Görpelioğlu S, Filiz TM. Değirmendere Aile Hekimliği Polikliniğine Başvuran Erişkin Hastalarda Obezite Sıklığı ve Eşlik Eden Hastalıklarla ilişkisi: Bir Olgu Kontrol Çalışması. Türk Aile Hek Derg 2003;7:117-21.

9. Akman M, Budak Ş, Kendi M. Genel Dahiliye Polikliniğine Başvuran Hastalarda Obezite Sıklığı Ve İlişkili Sağlık Problemleri. Marmara Med J 2004;17;113-20.

10. Arslan C, Ceviz D. Ev Hanımı ve Çalışan Kadınların Obezite Prevalansı ve Sağlıklı Yaşam Biçimi Davranışlarının Değerlendirilmesi. F Ü Sağ Bil Derg 2007;21:211-20.
11. Erkol A, Khorshid L. Obezite; Predispozan Faktörler ve Sosyal Boyutun Değerlendirilmesi. SSK Tepecik Hast Derg 2004;14:101-7.

12. Baughman K, Logue E, Sutton K, Capers C, Jarjoura D, Smucker W. Biopsychosocial characteristics of overweight and obese primary care patients: do psychosocial and behavior factors mediate sociodemographic effects? Prev Med 2003;37:129-37.

13. Park YW, Zhu S, Palaniappan L, Heshka S, Carnethon MR, Heymsfield SB. The metabolic syndrome: prevalence and associated risk factor findings in the US population from the Third National Health and Nutrition Examination Survey, 1988-1994. Arch Intern Med 2003;163:427-36.

14. Mithat Bahçeci. Obezite rehberi. Tükiye Endokrin ve Metabolizma Derneği Obezite, Dislipidemi, Hipertansiyon Çalışma Grubu. 2011;50-80.

15. Xu Z, Qi X, Dahl AK, Xu W. Waist-to-height ratio is the best indicator for undiagnosed type 2 diabetes. Diabet Med 2013;30:201-7.

16. Ashwell M, Gunn P, Gibson S. Waist-to-height ratio is a better screening tool than waist circumference and BMI for adult cardiometabolic risk factors: systematic review and meta-analysis. Obes Rev 2012;13:275-86. 